\title{
SICKLE CELL DISEASE - CASE REPORTS
}

\author{
Adhikari R C, Shrestha T B*, Shrestha R B \\ Subedi R C, Parajuli K P*, Dali S
}

\section{ABSTRACT}

Sickle cell diseases are inherited hematological diseases, prevalent in certain parts of the world. We report two cases of sickle cell diseases, first being sickle cell $\boldsymbol{\beta}$-thalassaemia and second homozygous sickle cell disease (SS). Our first case was 5 year old boy presenting with hemolytic anaemia \& hepatosplenomegaly having sickle cell $\boldsymbol{\beta}$-thalassaemia disease . Second case was 17 years female presenting with hemolytic anaemia \& joint pain having homozygous sickle cell disease.

Key Words: Homozygous sickle cell disease, sickle cell $\beta$ - thalassaemia, hemoglobin electrophoresis.

\section{INTRODUCTION}

Sickle cell diseases are hereditary disorders, and the common inherited hematological disease affecting humans. These disorders include the sickle cell trait, homozygous sickle cell disease and the combined with other hemoglobins. The clinical manifestation of the disease is quite variable and includes anemia, pain or infection.

Sickle cell disease is common in tropical Africa, the Caribbean, the middle east and the Indian subcontinent. $40 \%$ of the population in certain countries of tropical Africa have sickle cell trait. ${ }^{1}$ To our knowledge, no cases of sickle cell disease were reported from Nepal. We here report two cases of sickle cell disease. Our aim is to emphasize that sickle cell diseases are existing in Nepal and they simply remain undiagnosed due to lack of availability of very simple laboratory tests.

\section{CASE REPORTS}

\section{Case no.1}

A 5 year old boy (Ethnic group-Tharu), inhabitant of Nawalparasi district, Nepal presented with complaints of yellowish colouration of eye, occasional abdominal pain and on

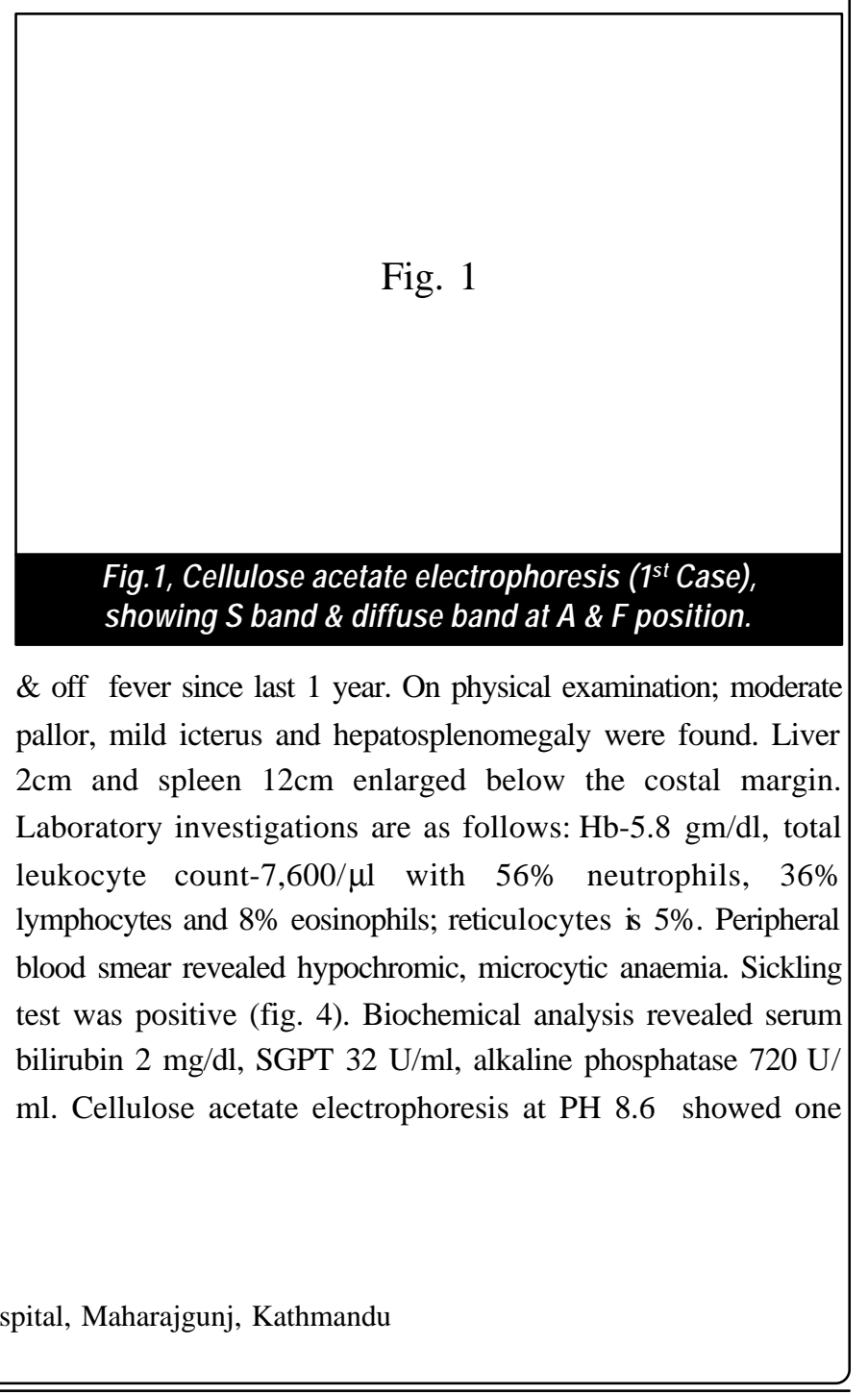

1. TU Teaching Hospital, Maharajgunj, Kathmandu, Nepal.

Address for correspondence : Dr. Ram Chandra Adhikari Lecturer, Department of Pathology

Tribhuvan University Teaching Hospital, Maharajgunj, Kathmandu

Email: rcadhikari@hotmail.com

.INMA .laniıary - Fehriary 20ก? 4? 
Fig. 2

Fig.2, Peripheral blood smear (2 ${ }^{\text {nd }}$ Case), showing hypochronic, microcytic red blood cells with occasional sickle cells.

major band at 'S' position and diffuse band at 'A' \& 'F' position (fig.1). $\mathrm{HbF}$ constituted $11 \%$, estimated by alkali denaturation method. Patient's father was found to be sickle cell trait (with major band at 'A' position \& minor band at 'S' position). Mother was not available for investigations. So, positive sickling test, band at ' $\mathrm{S}$ ' position in cellulose acetate electrophoresis and presence of $11 \% \mathrm{HbF}$ confirmed the diagnosis of sickle-cell $\beta$ thalassaemia.

\section{Case no. 2}

A 17 years female (Ethnic group-Tharu), inhabitant of Nawalparasi district, Nepal presented with complaints of jaundice \& swelling of joints (knee, elbow, ankle etc.) periodically since last 15 years. Physical examination revealed moderate pallor and mild icterus. There was no organomegaly and joint deformity. Patient got repeated blood transfusion since 2 years of age. Laboratory investigations included: $\mathrm{Hb}-7.6 \mathrm{gm} /$ $\mathrm{dl}$, total leukocyte count - 15,800/ $\mathrm{ul}$; and platelets - 232,000/ $\mu 1$. Peripheral blood smear revealed hypochromic microcytic anaemia with occasional sickle cells (fig.2). Biochemical analysis revealed serum bilirubin $57 \mathrm{micro} \mathrm{mol} / \mathrm{l}$, SGPT $22 \mathrm{U} /$ 1, alkaline phosphatase $114 \mathrm{U} / 1$. Cellulose acetate electrophoresis at $\mathrm{pH} 8.6$ showed single band at 'S' position (fig.3). A sickling test was strongly positive (fig.4). Patient's

Fig. 3
Fig.3, Cellulose acetate electrophoresis ( $2^{\text {nd }}$ Case), showing strong $S$ band.
Fig. 4

\section{Fig.4, Showing positive sickling test.}

father was found to be sickle cell trait as bands at 'A' and 'S' position were detected. Mother was not available for investigations. So, positive sickling test with single band at ' $\mathrm{S}$ ' position in cellulose acetate electrophoresis confirmed the diagnosis of homozygous sickle-cell disease (SS).

\section{DISCUSSION}

The first case of sickle cell anaemia was reported by Herrick from West Indies in $1910 .^{2}$ The genetic basis for sickle cell anaemia was demonstrated in $19499^{3,4}$

The sickle cell disease includes wide variety of disorders in which the red cells undergo sickling when deoxygenated. The sickle cell disease results from substitution of thymine for adenine in the sixth codon of the $\beta$ gene (GAG $\leftarrow$ GTC) at chromosome 11 , thereby encoding valine, instead of glutamine. The coinheritance of sickle gene with other abnormal genes may occur. The usual co-inheritance occurs with a gene from thalassaemia $\&$ hemoglobin C. Our first case showed co-inheritance of sickle gene with $\beta$-thalassaemia gene; while second case was homozygous for $\mathrm{HbS}$ gene.

The susceptibility of red blood cells to sickle depends on the concentration of $\mathrm{HbS} .{ }^{5}$ The course \& severity of disease were infuenced by oxygen content of the inspired air, cardiac \& pulmonary status, dehydration, infection etc. Sickle-cell $\beta$ thalassemia is clinically characterized by anaemia, hepatosplenomegaly and painful crises. Our case showed anemia, hepatosplenomegaly \& abdominal pain. Homozygous sickle cell disease is characterized by frequent infection, splenomegaly, anaemia hemolytic), vaso-occlusive crises (bone/ joint pain), aplastic crises etc. Our case showed anaemia \& joint pains only.

The sickle cell diseases can be diagnosed by sickle test \& hemoglobin electrophoresis. Occasionally, hemoglobin separation by isoelectric focusing or high performance liquid 
chromatography, globin chain electrophoresis or structural analysis of hemoglobin may be required. The sickle test is a simple solubility test showing the presence of HbS. Our both cases show positivity for sickling. Hemoglobin electrophoresis detects \& distinguishes different hemoglobins. The hemoglobin of homozygous sicklecell diseases is composed of mainly $\mathrm{HbS}(75-95 \%)$ and no $\mathrm{HbA}$. Our case showed single strong $\mathrm{S}$ band. The hemoglobin of sicklecell $\beta$-thalassaemia disease is composed of $\mathrm{HbS}(60-85 \%), \mathrm{HbF}$ (2-10\%), $\mathrm{HbA}(10-30 \%)$ and $\mathrm{Hb} \mathrm{A} 2(4-8 \%)$. Our case showed S band \& diffuse band at $\mathrm{A} \& \mathrm{~F}$ position with $11 \% \mathrm{HbF}$. Hemoglobin A \& hemoglobin $\mathrm{F}$ can be differentiated by using citrate agar electrophoresis. ${ }^{6}$ It was not done in our case because of unavailability of this test.

So, this case report emphasizes the fact that sickle cell disorders are invariably occurring in Nepal (especially in Terai region $\&$ in Tharu ethnicity) and they can be easily screened by very simple sickle test.
REFERENCES

1. HellerP, BestWR, Nelson RB, BecktelJ . Clinical implication of sickle cell traitand G6PD in hospitalized blackmale patients. N EnglJ Med 1979;300:1001-5.

2. HerrickJ B. Peculiarelongated and sickle-shaped corpuscles in a case of severe anaemia. Arch Intem Med 1910;6:51721.

3. Ned J Y. The inheritance of sickle cell anaemia. science 1949;110:64-6.

4. BeetEA. The genetics of sickle cell traitin a Bantu tribe. Ann EurGen 1949;14:279-82.

5. Itano HA. Oualitative control of adulthemoglobinsynthesis: a multipleallele hypothesis. AmJ HumGenet 1953;5:34-6.

6. Dacie JV, Lewis SM. Practical haematology. $8^{\text {th }}$ edition. 1995:260.

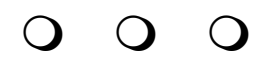

